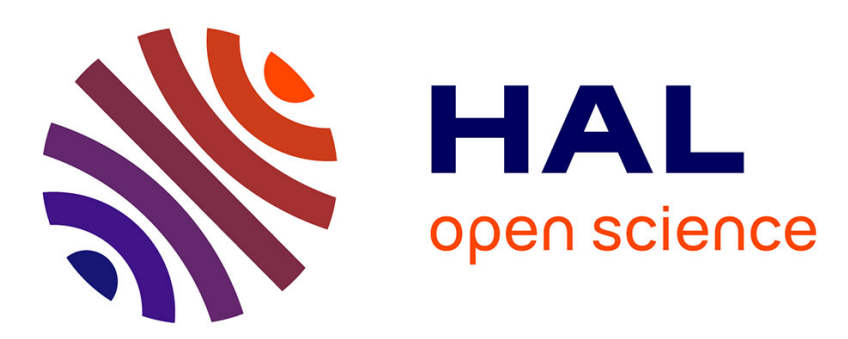

\title{
MODELING REGIONAL COASTAL EVOLUTION IN THE BIGHT OF BENIN, GULF OF GUINEA, WEST AFRICA
}

\author{
Ondoa Gregoire Abessolo, Magnus Larson, Rafael Almar, Bruno Castelle, \\ Edward J. Anthony, Johan Reyns
}

\section{To cite this version:}

Ondoa Gregoire Abessolo, Magnus Larson, Rafael Almar, Bruno Castelle, Edward J. Anthony, et al.. MODELING REGIONAL COASTAL EVOLUTION IN THE BIGHT OF BENIN, GULF OF GUINEA, WEST AFRICA. Coastal Sediments'19, May 2019, Tampa, United States. 10.1142/9789811204487_0178. hal-02394959

\section{HAL Id: hal-02394959 \\ https://hal.science/hal-02394959}

Submitted on 11 Dec 2019

HAL is a multi-disciplinary open access archive for the deposit and dissemination of scientific research documents, whether they are published or not. The documents may come from teaching and research institutions in France or abroad, or from public or private research centers.
L'archive ouverte pluridisciplinaire HAL, est destinée au dépôt et à la diffusion de documents scientifiques de niveau recherche, publiés ou non, émanant des établissements d'enseignement et de recherche français ou étrangers, des laboratoires publics ou privés. 


\title{
MODELING REGIONAL COASTAL EVOLUTION IN THE BIGHT OF BENIN, GULF OF GUINEA, WEST AFRICA
}

\author{
ONDOA GREGOIRE ABESSOLO ${ }^{1,2}$, MAGNUS LARSON $^{3}$, RAFAEL ALMAR ${ }^{1}$, \\ BRUNO CASTELLE ${ }^{4}$, EDWARD J. ANTHONY ${ }^{5}$, J. REYNS ${ }^{6,7}$
}

1. LEGOS, OMP, UMR 5566 (CNRS/CNES/IRD/Université de Toulouse), 14 Avenue Edouard Belin, 31400, Toulouse, France. gregsolo55@yahoo.fr, rafael.almar@ird.fr.

2. Ecosystems and Fisheries Resources Laboratory, University of Douala, BP 2701, Douala, Cameroun.

3. Department of Water Resources Engineering, Lund University, Box 118, S-221 00, Lund, Sweden. magnus.larson@tvrl.lth.se.

4. EPOC, OASU, UMR 5805 (CNRS - Université de Bordeaux), Allée Geoffroy SaintHilaire - CS 50023 - 33615, Pessac Cedex, France.bruno.castelle@u-bordeaux.fr.

5. Aix Marseille Univ., CNRS, IRD, INRA, Coll France, CEREGE, Aix-en-Provence, France.anthony@cerege.fr.

6. Department of Water Engineering, IHE-Delft, P.O. Box 3015, 2610 DA Delft, The Netherlands.J.Reyns@unesco-ihe.org.

7. Marine and Coastal Systems, Deltares, Delft, The Netherlands.

\begin{abstract}
The Bight of Benin coast is marked by the presence of three deepwater harbours which have affected the stability of the shoreline. In addition, several studies pointed out the overall diminution of sand supply due to the dams on Volta river channel and climate change effects. The combination of all these factors leads to a mixture of natural and artificial components affecting the coastline evolution in regional and long term scales. Here, we modeled the shoreline in the Bight of Benin, using the CASCADE model. The results show that the overall shape is well maintained and shoreline changes pretty well reconstructed. But, unresolved detailed information did not allowed to consider cross-shore sediment exchange and marked deviations can be observed. However, the CASCADE model can be used to investigate regional and long term solutions for decisions-makers in the concerned countries.
\end{abstract}

\section{Introduction}

In coastal management, a major issue is to understand the processes causing the variability of the coasts at different time scales. The damages and losses observed during extreme events and flooding are often a result of inadequate coastal management strategies. The long-term and large-scale adjustments of the shoreline to changes in wave climate, sea level rise, and sediment supply at open coasts can result into intensive erosion, threatening coastal societies, economical values, and valuable nature ecosystems (Ranasinghe 2016, Doody et al. 2004). Facing the increasingly intensive occupation of the coastal areas, it is of significant value to be able to predict the impact of such factors at several different time and space scales (French and Burningham 2009), leading to a 
need of managing the coastal area regionally and not locally. The regional modeling that spans decades to centuries can be used to address the full consequences and interactions of engineering activities, as well as the widescale influence of natural processes and features (Larson, Rosati, and Kraus 2002).

In the Bight of Benin, West Africa, Gulf of Guinea, recent studies (Anthony et al. 2019, Giardino et al. 2018, Dada et al. 2015, Almar et al. 2015) have focused on understanding the observed disturbance of the shoreline stability over the last few decades. Three main observations have been made: (i) this wave-dominated coast is particularly exposed to erosion and flooding due to wave climate and sea level rise (Giardino et al. 2018; Almar et al. 2015); (ii) the stability of this coast has been strongly affected by the breakwaters at several deep-water harbors (Lome, Cotonou, and Lagos) and groins (Anthony et al. 2019; Giardino et al. 2018; Laibi et al. 2014); (iii) existing river dams and decrease in rainfall reduced the sediment supply from the Volta and Niger rivers (Anthony et al. 2019; Giardino et al. 2018). The prediction of the spatial and temporal responses of this coastal system is therefore important to decisions-makers in the concerned countries, which are low-income countries with $70 \%$ of the population in the coastal zone.

Several models have been developed for this purpose, encompassing in their description hundreds of kilometers of the coast (Larson, Kraus and Hanson 2002; Jiménez and Sánchez-Arcilla 2004; Hanson et al. 2008; Hoan et al. 2011; Ranasinghe et al. 2013). However, these models have typically simplified the representation of the cross-shore exchange sediment exchange, employing sources and sinks with schematized values in time and space (Larson, Kraus and Hanson 2002). To improve the predictive capability of these models, longshore and cross-shore processes have been combined in a more rigorous manner, using physics-based formulations (Robinet et al. 2017; Vitousek et al. 2017). However, further simplifications are required as simulations are performed for large areas over long time periods (Larson et al. 2016). The regional coastal evolution model, known as CASCADE (Larson, Kraus and Hanson 2002) can be applied to stretches of coastline covering hundreds of kilometers, encompassing several barrier islands separated by inlets, including such phenomena as inlet creation, ebb- and flood-tidal shoal development, bypassing bars between beaches and inlets, channel dredging, regional trends in the shape of the coast, relative change in sea level, wind-blown sand, storms, periodic beach nourishment, and shore-protection structures such as groins and seawalls. Moreover, in the most recent development of the model complex cross-shore material exchange can be included (Larson et al. 2016). These exchanges include dune erosion, wind-blown sand, overwash, berm erosion, and longshore bar development based on simplified physics-based relationships. 
The overall objective of this work is to implement and develop the CASCADE model in the Bight of Benin, taking into account the main factors of shoreline variability of the area, to provide information for engineers, planners, and managers working on the decadal to century scale. First, background material and data were compiled for the study site with the purpose of calibrating the model. Second, the impact of the main harbors was considered and sediment transfer modeled. In a final step, the modeled

\section{The Bight of Benin coast}

The Bight of Benin in the Gulf of Guinea, West Africa, is the embayment located between the Volta River delta in the west (Ghana) and the Niger River delta (Nigeria) in the east, exhibiting a mildly embayed sand barrier system (Anthony et al. 2019). The Volta River delta and the Niger River delta are among the three largest deltas in West Africa. The total length of the considered coastline is about $400 \mathrm{~km}$, ranging between $1^{\circ}$ to $5^{\circ} \mathrm{E}$ in longitude, and 5 to $7^{\circ} \mathrm{N}$ latitude.

The coast is a microtidal open-environment, facing the South Atlantic Ocean and exposed to a dominant long swell-wave component that travels far from mid- to high latitudes $45-60^{\circ}$ in the South Atlantic and to the wind-sea component locally generated in the tropical band, $6^{\circ} \mathrm{N}$ to $15^{\circ} \mathrm{S}$ (Almar et al. 2015). This wave climate (mean values: $H s=1.36 \mathrm{~m}$; $T p=9.4 \mathrm{~s}$ ) drives an easterly longshore sediment transport ranging between 0 up to 1.2 million m3/year, depending on the location, according to Allersma and Tilmans (1993), Anthony and Blivi (1999) and Almar et al. (2015). Anthony and Blivi, (1999) identified the Volta River as the single most important fluvial sediment source for much of the sand barrier system of the Bight of Benin, with minor additional inputs (Anthony et al. 1996) from the Mono River in Benin. However, the Volta river discharge has been markedly reduced due to the decrease in rainfall over the Sahel since 1975 (Oguntunde et al., 2006), as well as the construction of the Akosombo dam between 1961 and 1965, approximately $100 \mathrm{~km}$ upstream from the sea (Anthony et al. 2019) and another smaller dam at Kpong, $24 \mathrm{~km}$ downstream of the Akosombo dam, constructed between 1977 and 1982. Three deepwater harbours have been constructed at the main cities on the bight coast: Lagos (1957), Cotonou (1962), and Lomé (1967). Recently, several groins have been built along the coast. An example is given by the field of nine groins of $100 \mathrm{~m}$ lengths and $20 \mathrm{~m}$ width over a distance of $3.5 \mathrm{~km}$, constructed near the city of Anèho (Togo) between 2012 and 2014.

The continental shelf is narrow, with widths of 15 to $33 \mathrm{~km}$ (Anthony et al. 2019; Giardino et al. 2018). Tides are semi-diurnal with a tidal range of approximately $0.3 \mathrm{~m}$ and $1.8 \mathrm{~m}$ for neap and spring tides, respectively, whereas 
sea level rise is about $+3.3 \mathrm{~mm} / \mathrm{year}$. The sediment size is medium-to-coarse sand, from 0.4 to $1 \mathrm{~mm}$, with a median grain size $\mathrm{D}_{50}=0.6 \mathrm{~mm}$.

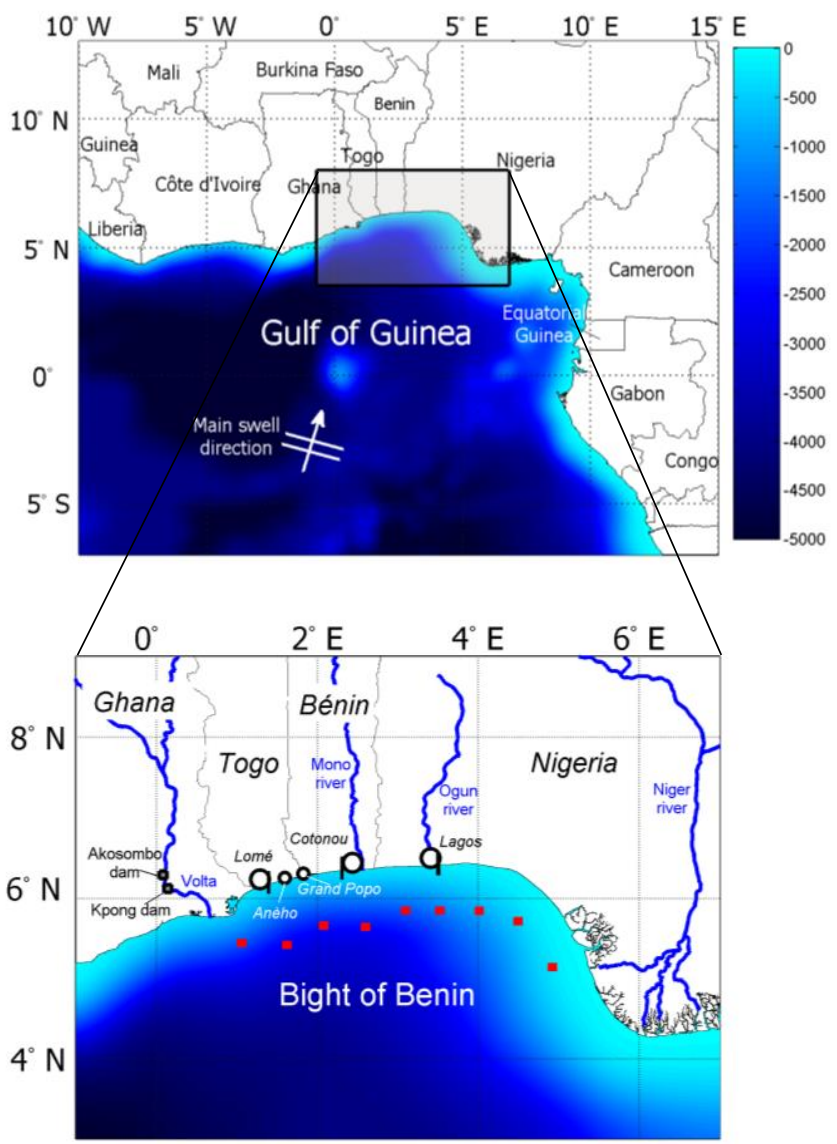

Fig. 1. The Bight of Benin in the Gulf of Guinea, with the three main harbors at Lomé, Cotonou and Lagos. Red points stand for stations where wave characteristics were extracted.

\section{Methods}

\section{Observed Regional Shoreline and Wave data (1990-2015)}

Shoreline evolution in the Bight of Benin was determined using the LANDSAT 4-8 satellite images. Three images for each of the years 1990, 2000, 2005, 2010, and 2015 were chosen and downloaded from the USGS data portal Earth Explorer to offer large individual coverage as well as robust and accurate determinations of shoreline change rates (accuracy $30 \times 30 \mathrm{~m}$ ). Rates of changes 
in shoreline position were digitized using the ArcMap extension module Digital Shoreline Analysis System (DSAS), version 4.3, coupled with ArcGIS®10. Details can be found in Anthony et al. 2019.

Hindcasted time series of waves, part of the ERA-Interim dataset (Sterl and Caires 2005), were extracted at seven different stations (see Fig. 1b) along the coast over the 1990-2015 period.

\section{Mathematical Modeling of Coastline Evolution: CASCADE}

The CASCADE model simulates coastal evolution at the regional scale covering $100 \mathrm{~s}$ of $\mathrm{km}$ and several decades. A typical coastal setting to which CASCADE may be applied is barrier islands separated by inlets with and without jetties, where the sediment is transferred around the inlets through the ebb-shoal complex (Larson et al. 2002). Sediment sources and sinks that vary in time and space are included in the model as well as a wide range of cross-shore processes, including dune erosion, overwash, wind-blown sand, bar-berm material exchange, erosion during storms and sea level rise. Focus was on reproducing the evolution around the main harbors in the area including Lagos, Cotonou, and Lomé.

\section{Results}

\section{Model setup and implementation}

CASCADE was implemented for a stretch of coastline along the Bight of Benin extending from a location just east of the Volta River to a location just west of Niger River. The modeled stretch is $374 \mathrm{~km}$ long, including the cities of Lome (Togo), Cotonou (Benin), and Lagos (Nigeria), which all have major harbors with structures that severely influence the sediment transport, causing downdrift erosion on a large scale (Anthony et al. 2019, Laibi et al. 2014). In addition, some of these harbors border lagoons or river mouths that further complicate the sediment transport and coastal evolution. However, in the present, initial phase of modeling, no effort was made to reproduce shoals and bars that might be present around the harbors, but they were described through a shore-perpendicular structures that block the sediment transport. After more information has been collected on the detailed morphology and its evolution around the harbors, it will be possible to add modeling of the shoals and bars, which will improve the description of the coastal evolution and lead to better resolution of the governing processes in these areas.

As a starting point in the modeling of this complex region, the boundaries of the modeling area were placed some distance away from the river deltas where 
historically (i.e., during the time period of observation, 1990-2015) no shoreline change was observed. This implies that a boundary condition corresponding to no longshore transport gradient can be employed, allowing sediment to be freely transported in and out over a boundary. Although such a boundary condition may work for the time period of study, simulations over longer periods, when significant changes to the system occur, may not reproduce the expected behavior. For example, major changes in the river sediment discharge that have occurred will in general not be described by the model with this type of boundary condition. A more extensive model approach should include the Volta and Niger River Deltas and the sediment discharge from major tributaries in the deltas.

The calculation grid employed a length step of $1000 \mathrm{~m}$ with a time step of $6 \mathrm{hr}$; the latter corresponded to the time resolution of the wave input. The positive $\mathrm{x}$-axis is directed from east to west, implying that an observer standing on the beach facing the ocean consider transport to the right to be positive (westward). In total seven offshore wave stations were used as input with linear interpolation between the stations when wave conditions were assigned along the grid (input waves varied spatially). The typical water depth at the stations is $40 \mathrm{~m}$, being more or less deep water. Since very limited information was available on the profile characteristics along the grid, the cross-shore sediment exchange routines were not activated, but the profile shape was kept constant. A median grain size of $0.5 \mathrm{~mm}$ was used throughout the grid; this was also due to lack of detailed information on the alongshore variation.

The simulations were performed with standard values in the model and comparison with the observed changes between 2000 and 2015 were performed. The shoreline from 1990 was not included in the simulation since this shoreline indicated significant general accumulation along most of the grid up until year 2000. This accumulation was typically in the range of 100 to $200 \mathrm{~m}$; no clear mechanism has been identified so far that explains this seaward of movement of the shoreline. Thus, it could not be described by the model.

\section{Simulation results}

The simulated shoreline evolution from 2000 to 2015 is displayed in Fig. 2 together with the measured shoreline at the end of the simulation. The calculated and observed shoreline change between 2000 and 2015 is also shown, since the scale of the bight makes it difficult to appreciate the detailed evolution of the shoreline. The influence of the tree harbors at Lome, Cotonou, and Lagos are easily identified with distinct areas of erosion and accumulation. Although qualitatively the shoreline response predicted by the model agrees with the observations, marked deviations occur locally and the magnitudes differ. Particularly the shoreline response around Lagos is not well resolved and the 
observed magnitude of seaward shoreline advance is much larger than the modeled. It is expected that more detailed information about morphology around the harbors will improve the simulations and form a basis for systematic model calibration and validation. The simulations also demonstrated that the model can maintain the overall shape of the bight, which tends to be difficult in this type of long-term simulations where diffusive processes smooth out shoreline gradients.

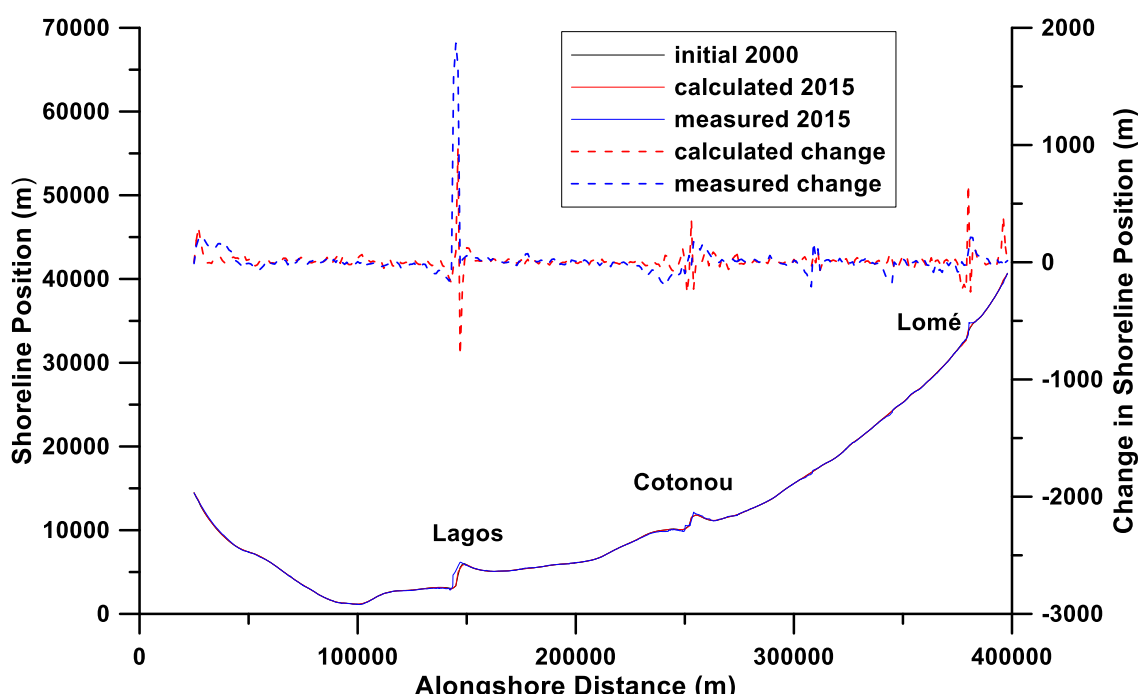

Fig. 2. Simulation of regional coastal evolution of the Bight of Benin between 2000 and 2015 with CASCADE. Calculated and measured shorelines at the end of the simulation period (2015) together with measured initial shoreline (2000). The calculated and measured shoreline change, from 2000 to 2015 , is also displayed. 


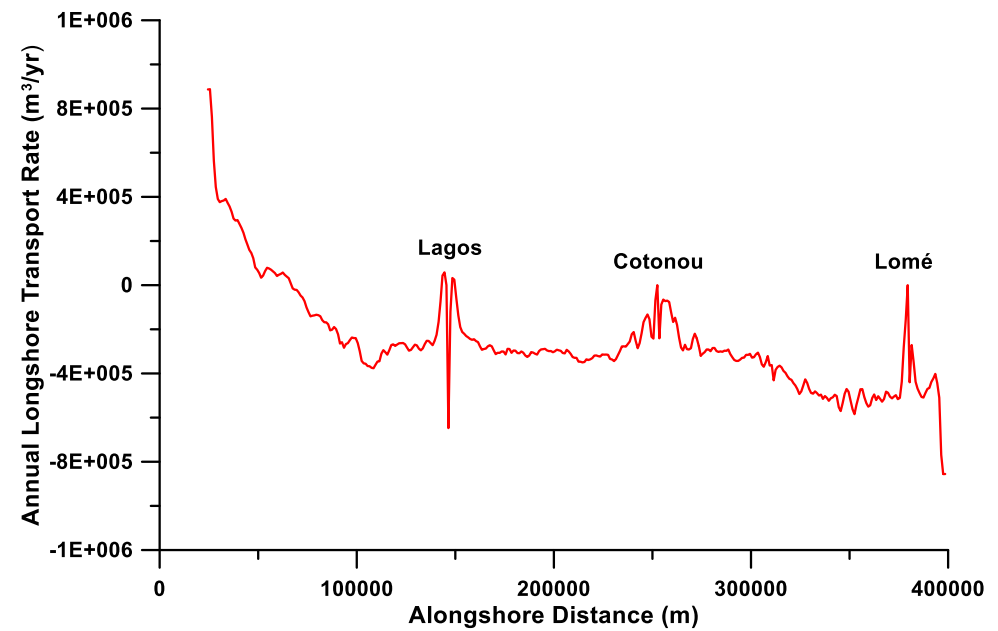

Fig. 3. Calculated annual net longshore transport rate based on the simulation between 2000 and 2015.

The derived mean annual transport rate along the bight is shown in Fig. 3 based on the simulation period 2000-2015. The large-scale transport pattern is predicted satisfactorily with the model calculation yielding local values in the expected range and in agreement with previous investigations (Almar et al. 2015). The net transport is to the east along most part of the bight, except for in the eastern part where the net transport is to the west (note that westward transport is taken positive, as previously explained).

\section{Conclusion}

Several recent works observed show that, for the last thirty years, the shoreline in the Bight of Benin has been destabilized, because of the progressively diminishing sand supply from the Volta river downstream of the Akosombo dam, the presence of the three harbors and climate change. In this study, the main objective is to model the evolution of the coast in the Bight of Benin, Gulf of Guinea. The results of implementing the CASCADE model on the coast of the Bight of Benin shows that the overall shape of the bight coast is well maintained. However, marked deviations are observed, particularly around Lagos harbor, as cross-shore sediment exchange routines were not activated. More detailed information about morphology and sediment supply around the harbors may improve the simulations. Moreover, it must be quite possible to derive the contributions of all the factors responsible of shoreline changes in the Bight of Benin, and therefore study what infrastructural solutions are adequate for this coast, in regional and long term scale. 


\section{Acknowledgements}

This publication was made possible through support provided by the IRD (French Institute of Research for Development).

\section{References}

Allersma, E., Tilmans, W.M.K., (1993). "Coastal conditions in West Africa - a review," J. Ocean Coast. Manag. 19, 199-240.

Almar, R., Kestenare, E., Reyns, J., Jouanno, J., Anthony, E.J., Laibi, R., Hemer, M., Du Penhoat, Y., Ranasinghe, R., (2015). "Response of the Bight of Benin (Gulf of Guinea, West Africa) coastline to anthropogenic and natural forcing, Part1: Wave climate variability and impacts on the longshore sediment transport," Continental Shelf Research, 110, 48-59.

Anthony, E.J., Almar, R., Besset, Reyns, J., Laibi, R., Ranasinghe, R., Abessolo Ondoa, G., Vacchi, M., (2019). "Response of the Bight of Benin (Gulf of Guinea, West Africa) coastline to anthropogenic and natural forcing, Part 2: Sources and patterns of sediment supply, sediment cells, and recent shoreline variations," Continental Shelf Research, 173 (2019) 93-103.

Anthony, E.J., Blivi, A.B., (1999). "Morphosedimentary evolution of a deltasourced, driftaligned sand barrier-lagoon complex, western Bight of Benin," Marine Geology 158, 161-176.

Anthony, E.J., Lang, J., Oyédé, L.M., (1996). "Sedimentation in a tropical, microtidal, wave-dominated coastal-plain estuary," Sedimentology 43, 665675 .

Doody, P., Ferreira, M., Lombardo, S., Lucius, I., Misdorp, R., Niesing, H., Salman, A., Smallegange, M., (2004). "Living with Coastal Erosion in Europe: Sediment and Space for Sustainability: Results from the EUROSION Study," European Commission, Luxembourg, p. 38.

French, J.R. and Burningham, H., (2009). "Coastal geomorphology: trends and challenges," Prog. Phys. Geogr. 33, 117-129.

Giardino, Schrijvershof, A.R., Nederhoff, C.M., de Vroeg, H., Brière, C., Tonnon, P.-K., Caires, S., Walstra, D.J., Sosa, J., van Verseveld, W., Schellekens, J., Sloff, C.J., (2018). "A quantitative assessment of human interventions and climate change on the West African sediment budget," 
Ocean Coastal Management, 156, 249-265,

Hanson, H., Larson, M., Kraus, N.C., (2010). "Long-term beach response to groin shortening, Westhampton Beach, Long Island, New York," Proceedings of the 31st International Coastal Engineering Conference, World Scientific.

Hoan, L.X., Hanson, H., Larson, M., (2011). "A mathematical model of spit growth and barrier elongation," Estuar. Coast. Shelf Sci. 93 (4), 468-477.

Jiménez, J., Sánchez-Arcilla, A., (2004). "A long-term (decadal scale) evolution model for microtidal barrier systems," Coastal Engineering 51 (8-9), 749764.

Laibi, R., Anthony, E., Almar, R., Castelle, B., Senechal, N., Kestenare, E., (2014). "Longshore drift cell development on the human-impacted Bight of Benin sand barrier coast, West Africa," Journal of Coastal Research, 70, 78-83.

Larson, M., Palalane, J., Fredriksson, C., Hanson, H., (2016). "Simulating crossshore material exchange at decadal scale. Theory and model component validation," Coastal Engineering, 116, 57-66.

Larson, M. and Kraus, N.C., (2003). "Modeling regional sediment transport and coastal evolution along the Delmarva Peninsula". Proceedings Coastal Sediments '03, ASCE (on CD).

Larson, M., Rosati, J.D., and Kraus, N.C., (2002). "Overview of regional coastal processes and controls," Coastal and Hydraulics Engineering Technical Note CHETN XIV-4, U.S. Army Engineer Research and Development Center, Vicksburg, MS.

http://chl.wes.army.mil/library/publications/chetn/pdf/chetn-xiv4.pdf.

Oguntunde, P.G., Friesen, J., van de Giesen, N., Savenije, H.H.G., (2006). "Hydroclimatology of the Volta River Basin in West Africa: Trends and variability from 1901 to 2002," Physics and Chemistry of the Earth, 31, $1180-1188$.

Palalane J., Fredriksson C., Marinho B., Larson M., Hanson H., Coelho C. (2016). "Simulating cross-shore material exchange at decadal scale. Model application," Coastal Engineering 116, 26-41. 
Ranasinghe, R., (2016). "Assessing climate change impacts on open sandy coasts: a review," Earth-Sci. Rev., 160, 320-332.

Ranasinghe, R., Duong, T., Uhlenbrook, S., Roelvink, D., Stive, M. (2013). "Climate change impact assessment for inlet-interrupted coastlines," Nat. Clim. Chang., 3, 83-87.

Robinet, A. (2017). "Modélisation de l'évolution long-terme du trait de côte le long des littoraux sableux dominés par l'action des vagues," $\mathrm{PhD}$ thesis, Bordeaux.

Sterl, A. and Caires, S. (2005). "Climatology, variability and extrema of ocean waves- the web-based KNMI/ERA-40 Wave Atlas," Int. J. Climatol., 25, 963-977.

Vitousek, S., Barnard, P.L., Limber, P, Li Erikson and Cole, B. (2017). "A model integrating longshore and cross-shore processes for predicting longterm shoreline response to climate change: CoSMoS-COAST," Journal of Geophysical Research, doi: 10.1002/2016JF004065. 